\title{
EFFECTS OF ANNEALING TIME ON THE RECOVERY OF CHARPY V-NOTCH PROPERTIES OF IRRADIATED HIGH-COPPER WELD METAL*
}

\author{
Shafik K. Iskander, Mikhail A. Sokolov, and Randy K. Nanstad \\ Metals and Ceramics Division \\ OAK RIDGE NATIONAL LABORATORY \\ P.O. Box 2008 \\ Oak Ridge, TN 37831-6151

\section{RECEIVED \\ MAY 171996

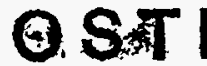

\begin{abstract}
*Research sponsored by the Office of Nuclear Regulatory Research, U.S. Nuclear Regulatory Commission, under Interagency Agreement DOE 1886-8109-8L with the U.S. Department of Energy under contract DE-AC05-84OR21400 with Lockheed Martin Energy Systems.
\end{abstract}

\begin{abstract}
The submitted manuscript has been authored by - contractor of the U.S. Government under contract No. DE-ACO5-84OR21400. Accordingly, the U.S. Government relains a nonexclusive. royalfy-free ficence to publish or reproduce the pubished form of this contribution, or allow others to do so, for U.S. Government purposes.
\end{abstract}

\section{DISCLAIMER}

This report was prepared as an account of work sponsored by an agency of the United States Government. Neither the United States Government nor any agency thereof, nor any of their employees, makes any warranty, express or implied, or assumes any legal liability or responsibility for the accuracy, completeness, or usefulness of any information, apparatus, product, or process disclosed, or represents that its use would not infringe privately owned rights. Reference herein to any specific commercial product, process, or service by trade name, trademark, manufacturer, or otherwise does not necessarily constitute or imply its endorsement, recommendation, or favoring by the United States Government or any agency thereof. The views and opinions of authors expressed herein do not necessarily state or reflect those of the United States Government or any agency thereof.

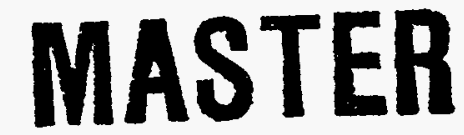


Shafik K. Iskander, ${ }^{1}$ Mikhail A. Sokolov, ${ }^{1}$ and Randy K. Nanstad ${ }^{1}$

\section{EFFECTS OF ANNEALING TIME ON THE RECOVERY OF CHARPY V-NOTCH PROPERTIES OF IRRADIATED HIGH-COPPER WELD METAL}

REFERENCE: Iskander, S. K., Sokolov, M. A., and Nanstad, R. K., "Effects of Annealing Time on the Recovery of Charpy V-Notch Properties of Irradiated High-Copper Weld Metal," Effects of Radiation on Materials: 17th Volume, STP 1270, David S. Gelles, Randy K. Nanstad, Arvind S. Kumar, and Edward A. Little, Editors, American Society for Testing and Materials, Philadelphia, 1996.

ABSTRACT: One of the options to mitigate the effects of irradiation on reactor pressure vessels is to thermally anneal them to restore the toughness properties that have been degraded by neutron irradiation. An important issue to be resolved is the effect on the toughness properties of reirradiating a vessel that has been annealed. This paper describes the annealing response of irradiated high-copper submerged-arc weld HSSI 73W. For this study, the weld has been annealed at $454^{\circ} \mathrm{C}\left(850^{\circ} \mathrm{F}\right)$ for lengths of time varying between 1 and 14 days. The Charpy V-notch 41-J (30-ft-lb) transition temperature $\left(\mathrm{TT}_{41 \mathrm{~J}}\right)$ almost fully recovered for the longest period studied, but recovered to a lesser degree for the shorter periods. No significant recovery of the $\mathrm{TT}_{415}$ was observed for a 7-day anneal at $343^{\circ} \mathrm{C}\left(650^{\circ} \mathrm{F}\right)$. At $454^{\circ} \mathrm{C}$ for the durations studied, the values of the upper-shelf impact energy of irradiated and annealed weld metal exceeded the values in the unirradiated condition. Similar behavior was observed after aging the unirradiated weld metal at 460 and $490^{\circ} \mathrm{C}$ for 1 week.

KEY WORDS: annealing, irradiation, recovery, Charpy V-notch, transition temperature, upper-shelf energy, copper, weld metal, toughness, reactor pressure vessel

\section{INTRODUCTION}

Some early nuclear power reactor pressure vessels (RPVs) fabricated from certain types of steels may not meet the pertinent regulatory requirements as they near end of life. These regulatory requirements are promulgated in Appendix $\mathrm{G}$ of Title 10 of the Code of Federal Regulations, Part 50, "Fracture Toughness Requirements." It is believed that in

${ }^{1}$ Metals and Ceramics Division, Oak Ridge National Laboratory, Oak Ridge, TN 37831-6151. 
the next decade or so, several vessels may exceed the limits set by the pressurized thermal shock reference temperature. In that case, thermal annealing may be needed to mitigate effects of neutron embrittlement on fracture toughness. A dozen or so RPVs have already been thermally annealed in Eastern Europe [1].

Historically, the toughness of RPVs has been monitored through surveillance programs in which predominantly Charpy V-notch (CVN) specimens are placed in capsules that are withdrawn and tested periodically. The degradation of fracture toughness is estimated from both the radiation-induced shit of the CVN 41-J (30-ft-lb) transition temperature ( $\left.\Delta \mathrm{TT}_{415}\right)$ as well as the decrease in the upper-shelf energy (USE) level. The fracture toughness of irradiated RPV material is estimated from the American Society of Mechanical Engineers (ASME) Boiler and Pressure Vessel Code fracture toughness curves [2] by shifting them upward in temperature by $\Delta \mathrm{TT}_{4 \mathrm{y}}$. Recent advances in fracture mechanics allow the determination of the fracture toughness of the thick-section RPV steels from relatively small fracture toughness specimens, but for some of the earlier RPVs, the use of their CVN-based surveillance data and specimens will probably play a key role in the judgement of the efficacy of the anneal.

This paper discusses the effect of annealing on the CVN impact energy of irradiated high-copper welds. This research was performed within the Heavy Section Steel Irradiation (HSSI) Program sponsored by U.S. Nuclear Regulatory Commission at the Oak Ridge National Laboratory (ORNL). The long-term objectives of the HSSI Program annealing task are to determine the rates of fracture toughness degradation due to reembrittlement after annealing several critical irradiated materials and to relate them to the corresponding rates for unirradiated material upon irradiation, or to the recovery of the $\Delta \mathrm{TT}_{4 \mathrm{IJ}}$ of irradiated and annealed material. The rate of reembrittlement is an important consideration since it will determine how long the plant may be safely operated after it is annealed. Most of the available data dealing with the recovery and reembrittlement response are based on the CVN impact energy, which must then be correlated with the fracture toughness.

\section{DESCRIPTION OF MATERIAL USED}

The commercially fabricated submerged arc-weld used for this study, designated HSSI weld 73W, has been very extensively characterized in other HSSI tasks [3-7]. Large variations in the copper content (from 0.22 to $0.46 \%$ ) have been observed in welds fabricated using weld wire with copper coating [8]. To avoid these large variations, the $73 \mathrm{~W}$ weld wire was fabricated with copper added to the melt, consequently, the variation in copper content is very small. The chemical composition and standard deviation of HSSI Weld 73W, obtained from a large number of analyses, is shown in Table 1.

The CVN specimens used in this study were slightly smaller in one cross-sectional dimension than the standard full-size CVN specimens. This slightly smaller dimension of the specimens was dictated by the space available in the HSSI Fifth Irradiation Series capsules [9]. A typical arrangement of these specimens is shown in Fig. 1. The dimension 


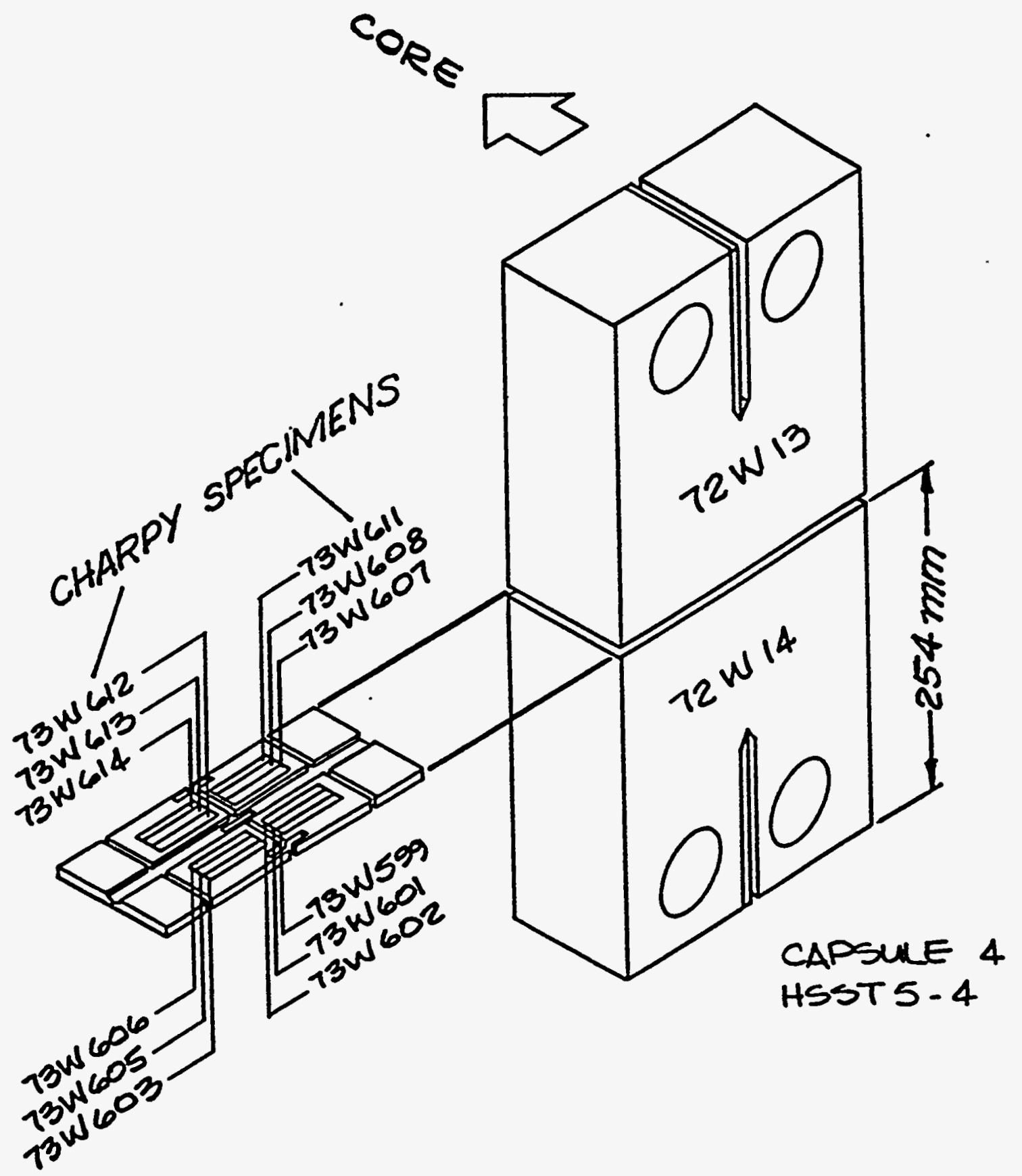

FIG. 1--The undersize Charpy V-notch specimens were irradiated in the available space of the Fifth Irradiation Series capsules. 
normal to the notch of the "undersize" CVN specimens is $95 \%$ of full-size specimens, as shown in Fig. 2.

There were 120 undersized CVN specimens irradiated as part of the HSSI Fith Irradiation Series, 12 in each of 10 capsules. They were irradiated at a nominal temperature of $288^{\circ} \mathrm{C}$, and to average exposures of $1.8 \times 10^{19}$ neutrons $/ \mathrm{cm}^{2}(>1 \mathrm{MeV})$, $1.1 \times 10^{20}$ neutrons $/ \mathrm{cm}^{2}(>0.1 \mathrm{MeV})$, and 0.040 displacements per atom. The irradiation was performed in the Oak Ridge Research Reactor over a period of about 2 months, with an average flux of $3.4 \times 10^{12}$ neutrons $/\left(\mathrm{cm}^{2}-\mathrm{s}\right)(>1 \mathrm{MeV})$; full details are presented elsewhere [9].

TABLE 1-Chemical composition and standard deviation of the various elements analyzed for HSSI weld 73W

\begin{tabular}{|c|c|c|c|c|c|c|c|c|c|}
\hline \multicolumn{10}{|c|}{ (wt \% and standard deviation) } \\
\hline $\mathbf{C}$ & $\mathrm{Mn}$ & $\mathbf{P}$ & $\mathrm{S}$ & $\mathrm{Si}$ & $\mathrm{Cr}$ & $\mathrm{Ni}$ & $\mathrm{Mo}$ & $\mathrm{Cu}$ & $\mathrm{V}$ \\
\hline 0.098 & 1.56 & 0.005 & 0.005 & 0.45 & 0.25 & 0.60 & 0.58 & 0.31 & 0.003 \\
0.007 & 0.026 & 0.0004 & 0.0006 & 0.028 & 0.006 & 0.006 & 0.009 & 0.010 & 0.0001 \\
\hline
\end{tabular}

The results of CVN impact testing of unirradiated undersize CVN specimens are compared to those of full-size specimens in Fig. 3. Each of the curves shown is a hyperbolic tangent fit by nonlinear regression to the experimental results of testing 55 and 85 specimens for the undersize and full-size specimens, respectively. Although the slope of the curves in the transition region for the undersize specimens is somewhat steeper than for the full-size specimens, the CVN 41-J transition temperatures ( $T_{41 \mathrm{y}}$ ) are approximately equal. As will be shown later, this difference in slope was not apparent in testing a smaller number of specimens (10 to 18) of either the irradiated or irradiated and annealed specimens of nominally the same geometry. Thus, this difference in slope may be due to the sensitivity of the undersize specimen to variations in the notch depth.

\section{MATERIAL CONDITIONS INVESTIGATED}

The irradiated CVN specimens were annealed at two temperatures, 343 and $454^{\circ} \mathrm{C}$. These two temperatures have been often investigated as approximate lower and upper bounds of probable annealing temperatures [10]. The $343^{\circ} \mathrm{C}$ temperature could be used for a wet anneal. This is considerably simpler to perform than a dry anneal at $454^{\circ} \mathrm{C}$ since the reactor internals would not have to be removed. A 168 -h annealing time was investigated for the lower temperature, and, since the recovery of the $\mathrm{TT}_{4 \mathrm{U}}$ was insignificant, no other annealing times were investigated. Four annealing times varying 


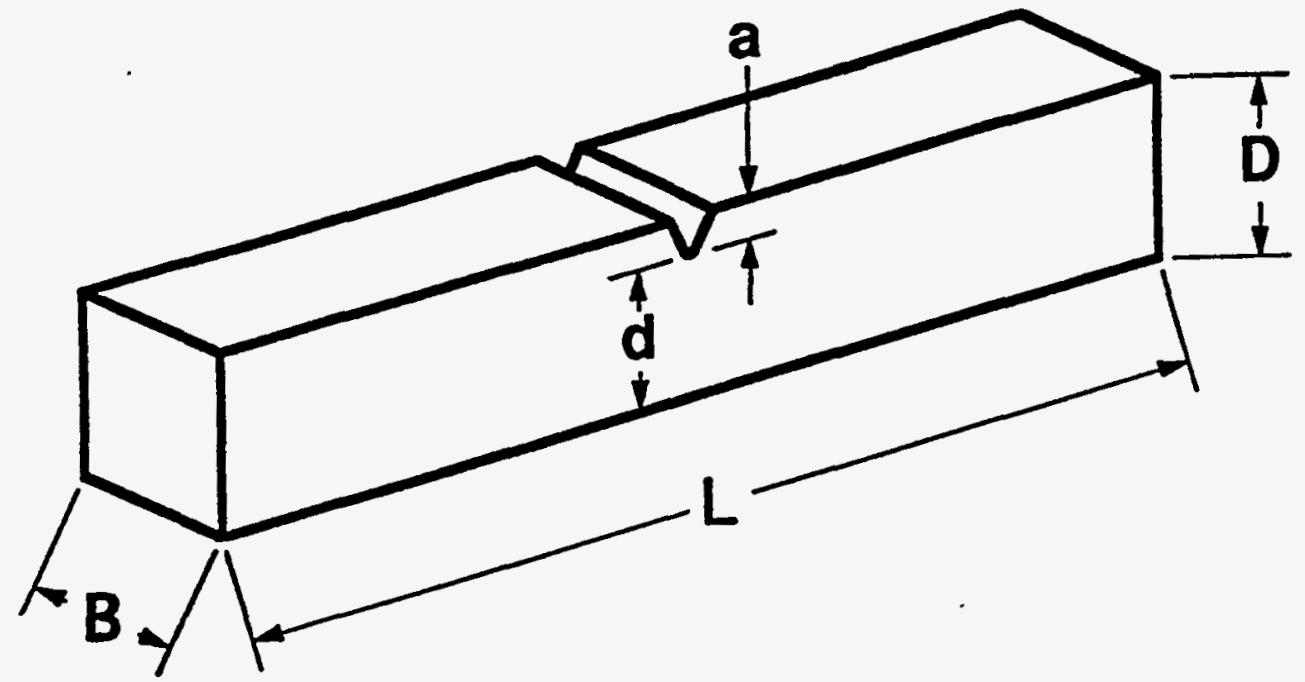

\begin{tabular}{lcccccc}
\hline & $\mathrm{L}$ & $\mathrm{B}$ & $\mathrm{D}$ & $\mathrm{d}$ & $\mathrm{a}$ & \\
& $\begin{array}{c}\text { (in) } \\
(\mathrm{mm})\end{array}$ & $\begin{array}{c}\text { (in) } \\
(\mathrm{mm})\end{array}$ & $\begin{array}{c}\text { (in) } \\
(\mathrm{mm})\end{array}$ & $\begin{array}{c}\text { (in) } \\
(\mathrm{mm})\end{array}$ & $\begin{array}{c}\text { (in) } \\
(\mathrm{mm})\end{array}$ & a/D \\
\cline { 2 - 7 } & 2.165 & 0.394 & 0.375 & 0.303 & 0.072 & 0.191 \\
Undersized specimens & 55.00 & 10.00 & 9.52 & 7.71 & 1.82 & \\
& & & & & & \\
Standard specimens & 2.165 & 0.394 & 0.394 & 0.315 & 0.079 & 0.200 \\
& 55.00 & 10.00 & 10.00 & 8.00 & 2.00 & \\
\hline
\end{tabular}

FIG. 2--Dimensions of the undersize Charpy V-notch specimens compared to the standard full-size specimens. 

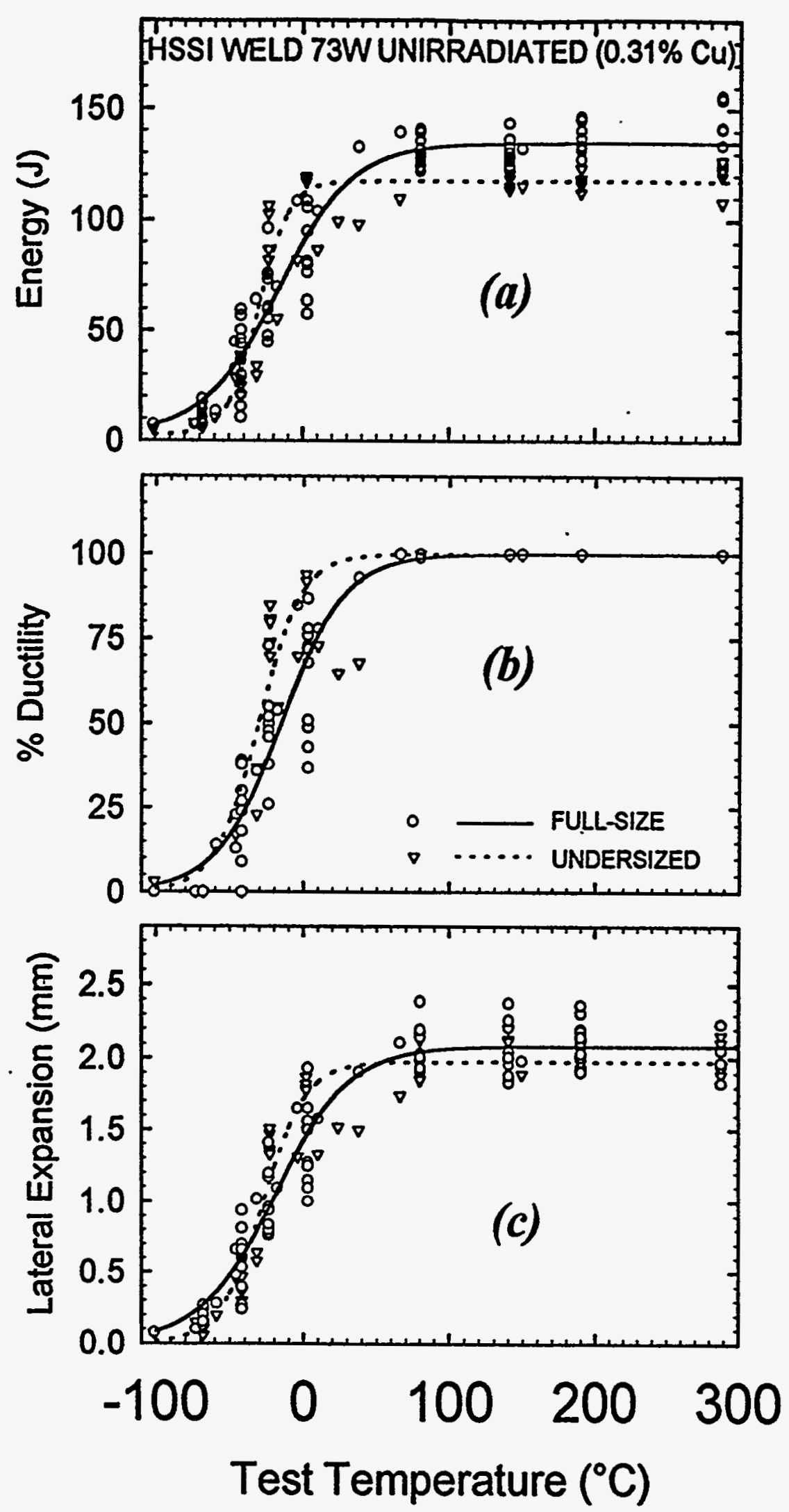

FIG. 3--Comparison of the Charpy V-notch impact energy of the unirradiated undersize HSSI weld 73W specimens to the full-size specimens: (a) energy, (b) ductile appearance, and (c) lateral expansion. 
from 1 day to 2 weeks $\left(336 \mathrm{~h}\right.$ ) were investigated at a temperature of $454^{\circ} \mathrm{C}$. One of the results of this investigation is that annealing increased the USE to values greater than the unirradiated specimens. This was not unexpected since other investigators have also noted such an effect. Annealing, tempering and aging effects are diffusion processes where temperature is the dominant parameter and time is of secondary influence. As part of the original fabrication procedure, the 73 W weld was postweld heat treated (PWHT) at a temperature of $607^{\circ} \mathrm{C}$ for $40 \mathrm{~h}$, and thus exposure at the lower temperature of $454^{\circ} \mathrm{C}$ for $168 \mathrm{~h}$ would not be expected to have any effect. To determine whether this increase in USE was due to irradiation, unirradiated specimens were also aged at 460 and $490^{\circ} \mathrm{C}$. The conditions investigated have been summarized in Table 2.

TABLE 2--Material conditions investigated

\begin{tabular}{|l|c|}
\hline \multicolumn{1}{|c|}{ Material condition } & $\begin{array}{c}\text { Aging or annealing time } \\
\text { (h) }\end{array}$ \\
\hline Unirradiated & 168 \\
Unirradiated and aged at $460^{\circ} \mathrm{C}\left(860^{\circ} \mathrm{F}\right)$ & 168 \\
Unirradiated and aged at $490^{\circ} \mathrm{C}\left(914^{\circ} \mathrm{F}\right)$ & 168 \\
Irradiated & \\
Irradiated and annealed $343^{\circ} \mathrm{C}\left(650^{\circ} \mathrm{F}\right)$ & $24,96,168,336$ \\
\hline
\end{tabular}

\section{TEST RESULTS}

The results of CVN tests on 73W welds for the conditions investigated are shown in Figs. 4 through 8. The recovery of CVN impact properties is measured by the changes in values of the USE and $\mathrm{TT}_{425}$ before and after annealing when compared to the unirradiated values. The values of the USE and $\mathrm{TT}_{4 \mathrm{JJ}}$ were calculated from a nonlinear regression fit of a hyperbolic tangent equation to the $\mathrm{CVN}$ impact energy results. The hyperbolic tangent equation was also fitted to the experimental values of percent ductile shear appearance and lateral expansion, and is of the form:

$$
y=\frac{U S+L S}{2}+\frac{U S-L S}{2} \operatorname{Tanh}\left(\frac{T-M T T}{T Z W / 2}\right),
$$

where

$$
y=\text { energy, percent ductile shear appearance, or lateral expansion }
$$

US and LS = upper- and lower-shelf values, respectively,

$T=$ test temperature,

MTT = mid-transition temperature, and,

$\mathrm{TZW}=$ transition zone width. 


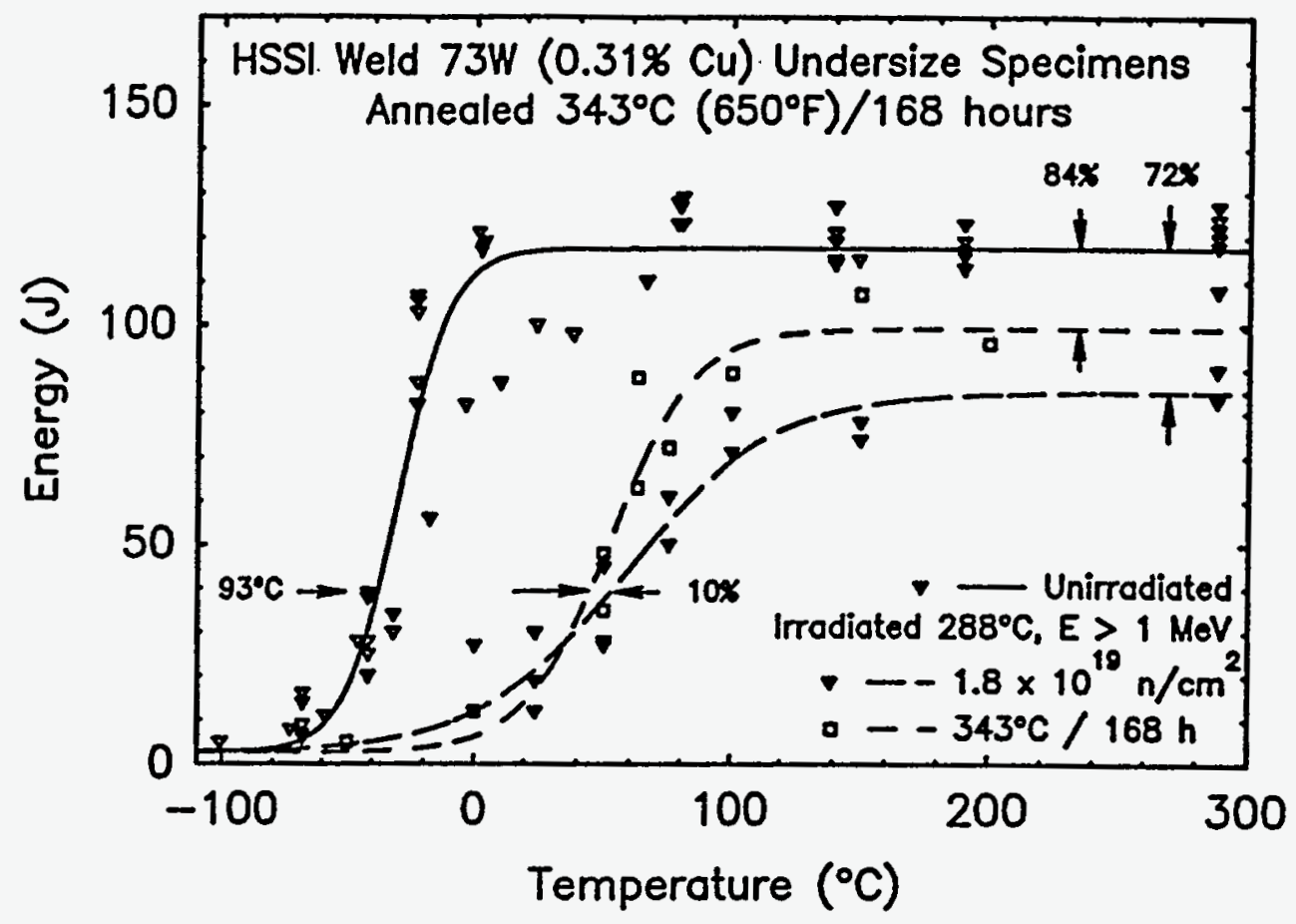

FIG. 4--Results of testing undersize irradiated Charpy V-notch specimens annealed at $343^{\circ} \mathrm{C}$ for $168 \mathrm{~h}$ compared to specimens in the unirradiated and irradiated conditions. The percent recovery is also indicated.

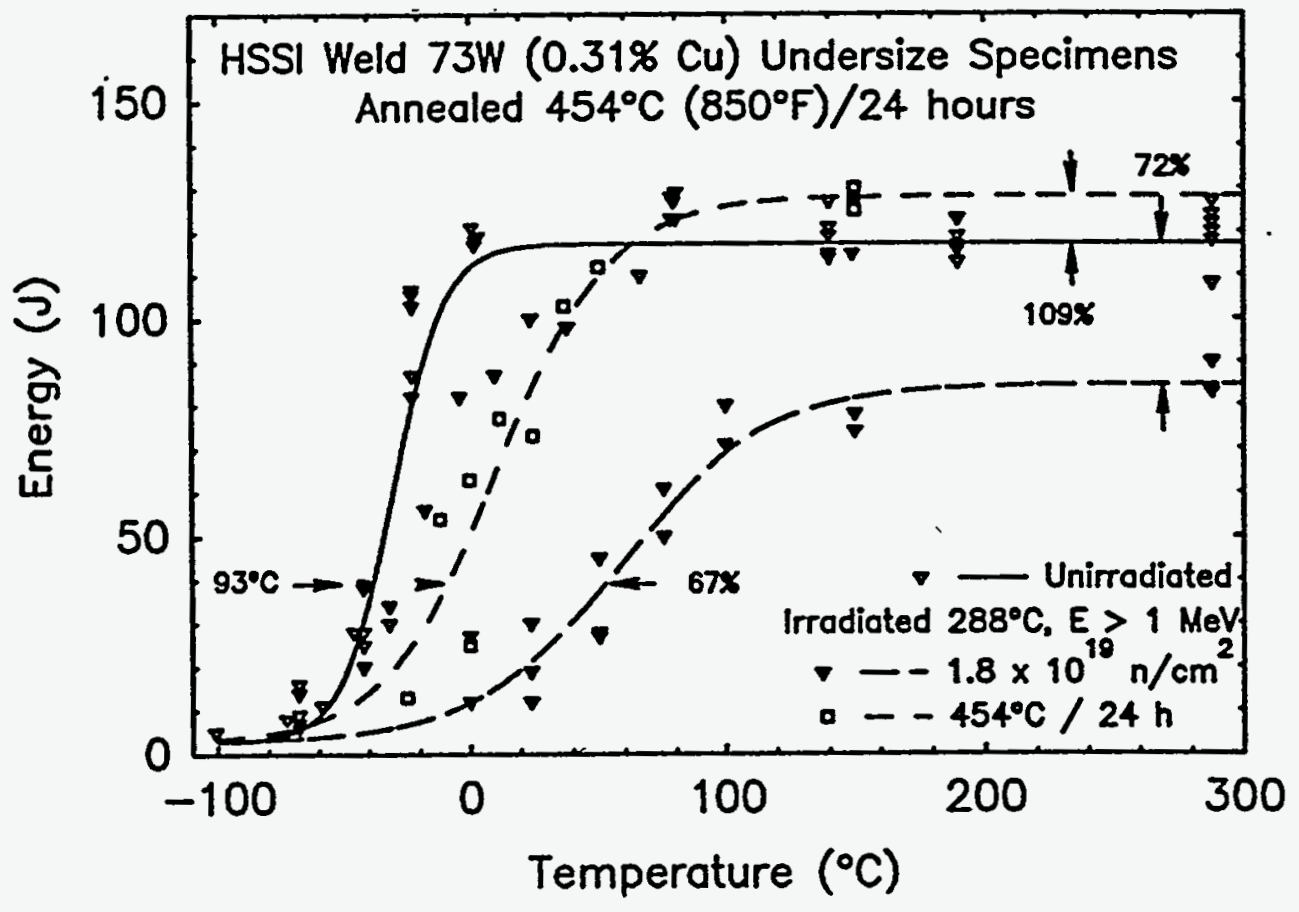

FIG. 5--Results of testing undersize irradiated Charpy V-notch specimens annealed at $454^{\circ} \mathrm{C}$ for $24 \mathrm{~h}$ compared to specimens in the unirradiated and irradiated conditions. The percent recovery is also indicated. 


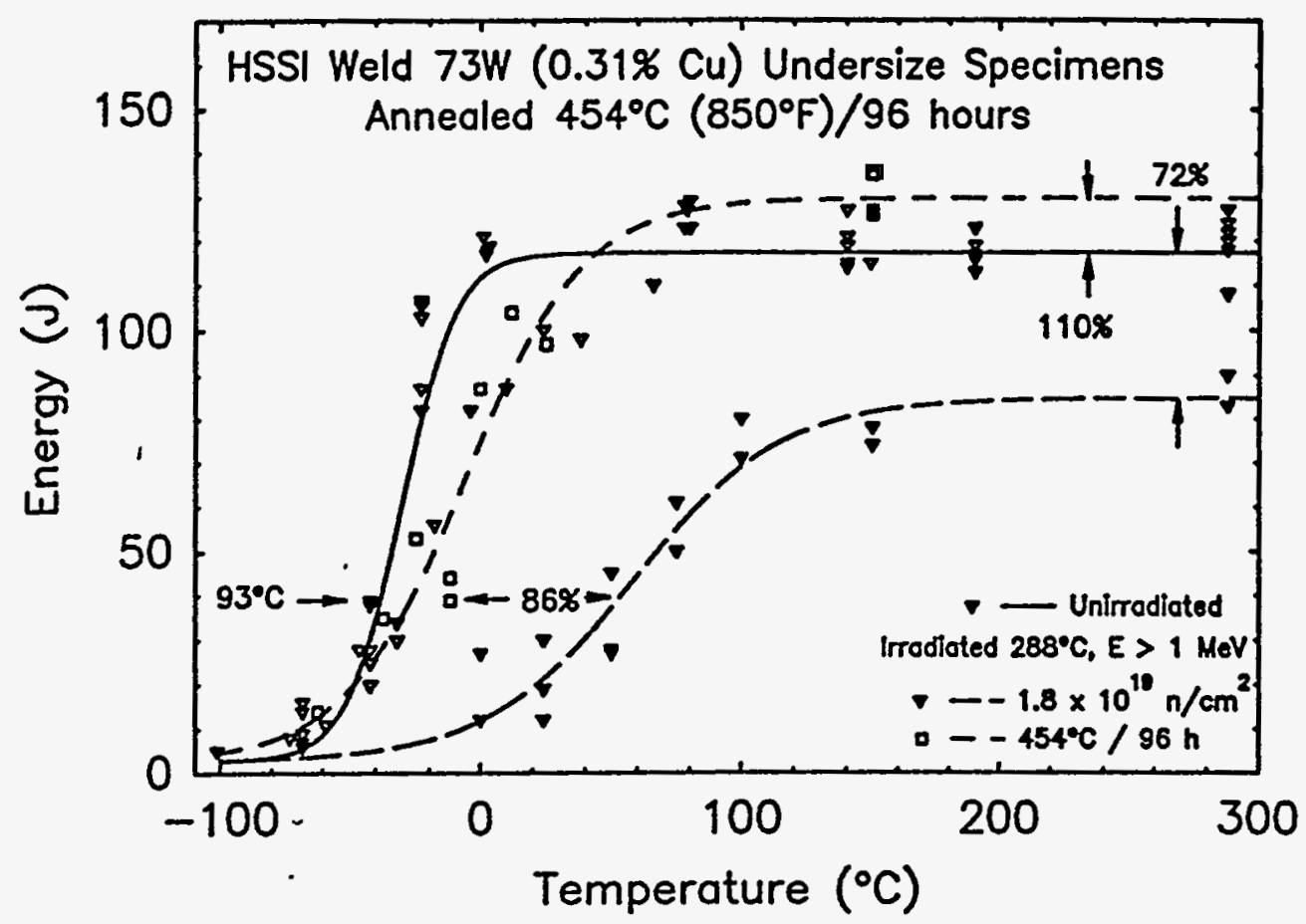

FIG. 6--Results of testing undersize irradiated Charpy V-notch specimens annealed at $454^{\circ} \mathrm{C}$ for $96 \mathrm{~h}$ compared to specimens in the unirradiated and irradiated conditions. The percent recovery is also indicated.

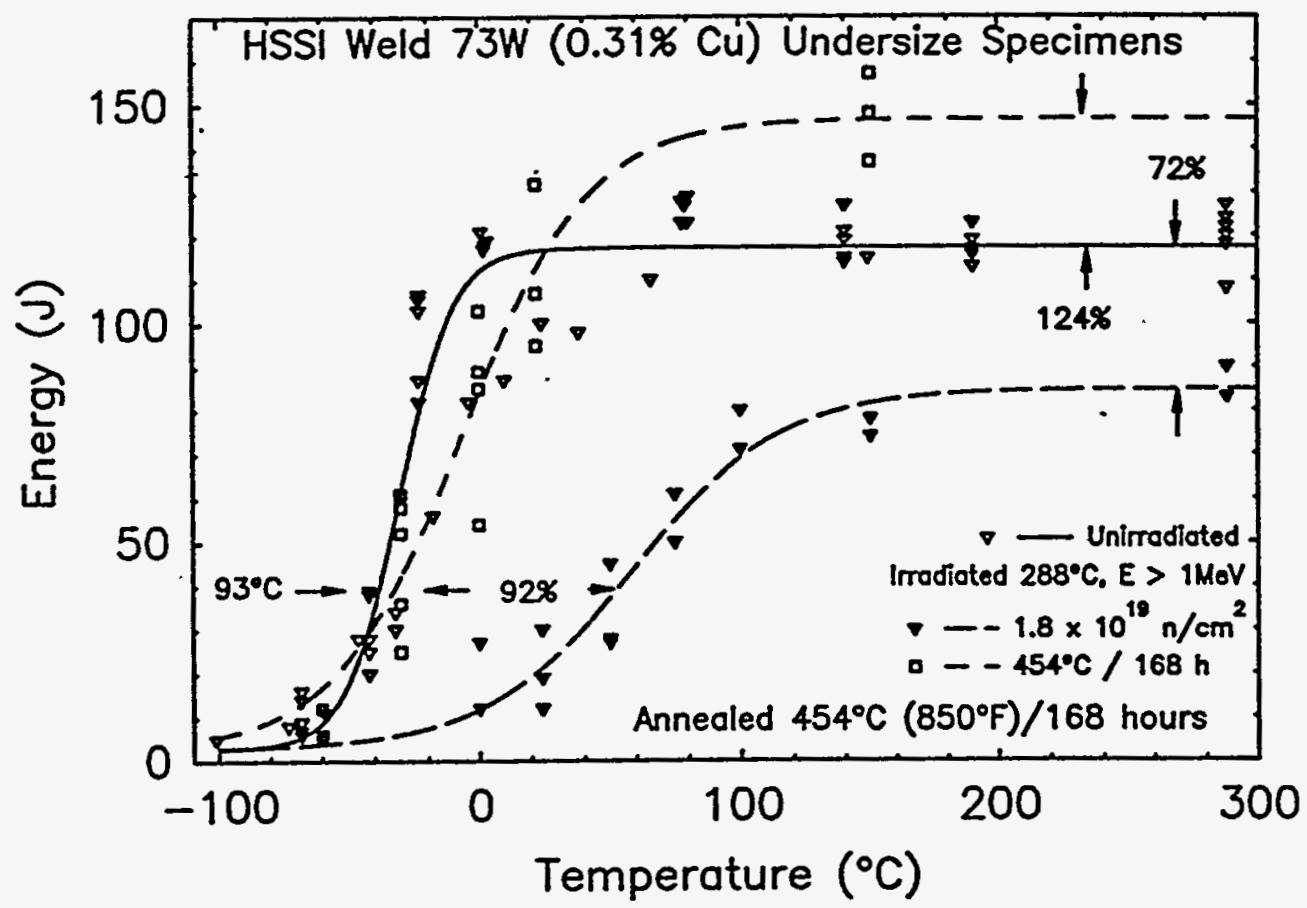

FIG. 7--Results of testing undersize irradiated Charpy V-notch specimens annealed at $454^{\circ} \mathrm{C}$ for $168 \mathrm{~h}$ compared to specimens in the unirradiated and irradiated conditions. The percent recovery is also indicated. 
In the case of fitting energy values, the LS was prescribed to be $2.7 \mathrm{~J}$, the average value obtained by testing five submerged-arc welds at liquid nitrogen temperature of $-196^{\circ} \mathrm{C}$ [8]. For lateral expansion and percent ductile shear appearance, the value of LS was prescribed to be zero. The upper-shelf value, US, of ductile shear was prescribed to be $100 \%$. Except for these prescribed values, US, MTT, and TZW were fitting parameters.

The percent recovery of the $\mathrm{TT}_{41 \mathrm{~J}}$ is defined as the ratio of the residual transition temperature shift after annealing to the shift due to irradiation, $\Delta \mathrm{TT}_{41 \mathrm{~J}}$, or:

$$
\text { \% Recovery } \mathrm{TT}_{41 \mathrm{~J}}=\frac{\left[\mathrm{TT}_{41 \mathrm{~J}}\right]_{\mathrm{ir}}-\left[\mathrm{TT}_{41 \mathrm{~J}}\right]_{\mathrm{mm}}}{\left[\mathrm{TT}_{41 \mathrm{~J}}\right]_{\mathrm{irr}}-\left[\mathrm{TT}_{411}\right]_{\mathrm{unirr}}} \cdot 100,
$$

where $\mathrm{TT}_{4 \mathrm{JJ}}$ is the transition temperature at the 41-J energy level for the condition indicated by the outer subscript. Thus, the percent recovery is related to the shift, $\Delta \mathrm{TT}_{41 \mathrm{~J},}$, due to irradiation. Eq. (2):

The percent recovery of the USE could also be defined in an analogous manner to

$$
\% \text { USE Recovery }=\frac{U_{S E_{\text {ann }}}-U_{\text {USE }}}{U S E_{\text {unir }}-U S E_{\text {ir }}} \cdot 100 .
$$

On the other hand, changes in USE could be related to the unirradiated value, hence the percent recovery of the USE may also be defined as the ratio of the values of the USE in the irradiated and annealed (or aged) condition to the unirradiated condition:

$$
\% \text { USE Recovery }=\frac{\text { USE }_{2 n n}}{\text { USE }_{\text {unir }}} \cdot 100 .
$$

The disadvantage of Eq. (4) is that it makes no distinction in the case in which there is no recovery, indicating instead the loss of USE due to irradiation. Its main advantage is that, in cases of USE recovery (which is usually the case), the value relates to the unirradiated value. The disadvantage of Eq. (3) is that it cannot be applied to the case of unirradiated and aged material since there is no "irradiated" condition, while Eq. (4) allows comparisons between the changes of the USE in the unirradiated/aged and irradiated/annealed conditions. In this paper, both definitions of the percent recovery of USE have been used.

Except for the $343^{\circ} \mathrm{C}$ annealing temperature, which did not show any significant recovery in the $\mathrm{TT}_{41 \mathrm{~J}}$ as mentioned previously, the degree of $\mathrm{CVN}$ impact energy recovery was dependent on the length of annealing time. The $\mathrm{TT}_{4 \mathrm{IJ}}, \mathrm{USE}$, change, and percentage 
recovery for each of the conditions investigated has been summarized in Table 3. The percentage recovery of both the $T_{413}$ and the USE have been plotted in Fig. 9 for annealing at $454^{\circ} \mathrm{C}$.

\section{DISCUSSION}

Annealing the HSSI weld $73 \mathrm{~W}$ at $454^{\circ} \mathrm{C}$ for various lengths of time from 24 to $336 \mathrm{~h}$ has "over-recovered" the USE to values that exceeded the unirradiated ones, which has been also been observed in other investigations. As mentioned above, this increase cannot be explained by a simple time-temperature diffusion process in which temperature is the dominant parameter, since the weld was already PWHT at the higher temperature of $607^{\circ} \mathrm{C}$. Thus, the annealing at $454^{\circ} \mathrm{C}$ would not be expected to produce such changes in impact energy. Aging of unirradiated HSSI weld $73 \mathrm{~W}$ at 460 and $490^{\circ} \mathrm{C}$ for $168 \mathrm{~h}$ also increased the value of USE, so this increase could not be explained solely by changes in the material caused by irradiation. The recovery by annealing of the neutron irradiation-induced transition temperature shift can be understood, to a large degree, in terms of coarsening or over aging and decrease in the number density of the copper-rich precipitates that are believed to be the primary cause of the transition temperature shif [11]. However, the reasons for the over-recovery of the USE in the unirradiated and irradiated conditions is still unknown, and the HSSI program will continue to investigate this phenomenon. It should be noted that the aging of unirradiated HSSI weld $73 \mathrm{~W}$ did not cause any noticeable changes in the value of $\mathrm{TT}_{4 \mathrm{j} \text {. }}$.

Annealing HSSI weld $73 \mathrm{~W}$ at $454^{\circ} \mathrm{C}$ for $24 \mathrm{~h}$ recovered about two-thirds of the transition temperature shift caused by the neutron irradiation. Annealing at this temperature for longer times increases the recovery, but at a decreasing rate, so that doubling the annealing time from 168 to $336 \mathrm{~h}$ increases the percent recovery from 92 to $96 \%$, which may not be a reasonable return for the extra annealing time invested.

It is significant that in all the above cases of annealing of irradiated HSSI weld $73 \mathrm{~W}$ at $454^{\circ} \mathrm{C}$, the percentage recovery of the USE was greater than the percentage recovery of $\mathrm{TT}_{4 \mathrm{y}}$. This was also observed in other investigations as can be shown by . plotting the percent recovery of upper shelf versus the percent recovery of the $\mathrm{TT}_{4 \mathrm{~J}}$ for RPV steels. The data in Fig. 10 of the \% USE Recovery, Eq. (3), versus the $\%$ Recovery $\mathrm{TT}_{41 \mathrm{I}}$, Eq. (2), show that the majority of the data lie above the straight line with a 1:1 slope. The data in Fig. 10 were extracted from the ORNL test reactor data base [12]. This confirms the results from this investigation, namely that (1) the USE recovers faster than the $\mathrm{TT}_{41 \mathrm{~J}}$, and (2) the percentage recovery of USE, as defined by either Eqs. (3) or (4), is greater than $100 \%$. This result can be useful in cases where the number of specimens available is less than desired for an adequate determination of both $\mathrm{TT}_{415}$ and USE. More specimens could be devoted to determine the $\mathrm{TT}_{413}$, and fewer specimens could be used to confirm the recovery of the USE. 
TABLE 3--Values of the 41-J transition temperature and upper-shelf energy for all conditions investigated (blank values are unavailable or not applicable)

\begin{tabular}{|c|c|c|c|c|c|c|c|c|c|}
\hline \multirow[b]{2}{*}{ Condition } & \multicolumn{2}{|c|}{ Annealing/aging } & \multicolumn{3}{|c|}{ 41-J transition temperature } & \multicolumn{4}{|c|}{ Upper-shelf energy } \\
\hline & $\begin{array}{c}\text { Temperature } \\
\left({ }^{\circ} \mathrm{C}\right)\end{array}$ & $\begin{array}{l}\text { Time } \\
\text { (h) }\end{array}$ & $\begin{array}{l}\text { Value } \\
\left({ }^{\circ} \mathrm{C}\right)\end{array}$ & $\begin{array}{c}\text { Residual } \\
\text { shift }^{2} \\
\text { (K) }\end{array}$ & $\begin{array}{c}\text { Recoveryb } \\
(\%)\end{array}$ & $\begin{array}{c}\text { Value } \\
\text { (J) }\end{array}$ & $\begin{array}{c}\text { Change }^{\circ} \\
\text { (J) }\end{array}$ & $\begin{array}{c}\text { Change }^{d} \\
(\%)\end{array}$ & $\begin{array}{c}\text { Change } \\
(\%)\end{array}$ \\
\hline $\begin{array}{l}\text { Unnirradiated } \\
\text { Irradiated } \\
\text { Irradiated and annealed } \\
\text { Irradiated and annealed } \\
\text { Irradiated and annealed } \\
\text { Irradiated and annealed } \\
\text { Irradiated and annealed } \\
\text { Unirradiated and aged } \\
\text { Unirradiated and aged }\end{array}$ & $\begin{array}{l}343 \\
454 \\
454 \\
454 \\
454 \\
460 \\
490\end{array}$ & $\begin{array}{r}168 \\
24 \\
96 \\
168 \\
336 \\
168 \\
168\end{array}$ & $\begin{array}{r}-38 \\
55 \\
46 \\
-7 \\
-25 \\
-31 \\
-34\end{array}$ & $\begin{array}{r}93 \\
84 \\
31 \\
13 \\
7 \\
4\end{array}$ & $\begin{array}{l}10 \\
67 \\
86 \\
92 \\
96\end{array}$ & $\begin{array}{r}118 \\
85 \\
99 \\
128 \\
130 \\
147 \\
154 \\
138 \\
138\end{array}$ & $\begin{array}{r}-33 \\
-19 \\
10 \\
12 \\
29 \\
36 \\
20 \\
20\end{array}$ & $\begin{array}{r}42 \\
130 \\
136 \\
188 \\
209\end{array}$ & $\begin{array}{r}72 \\
84 \\
108 \\
110 \\
125 \\
131 \\
117 \\
117\end{array}$ \\
\hline $\begin{array}{l}\text { "Change from unirradiat } \\
\text { 'Defined by Eq. (2). } \\
\text { 'Change from unirradiat } \\
\text { dDefined by Eq. (3). } \\
\text {-Defined by Eq. (4). }\end{array}$ & lue, positive & es in & an & ease in & or shelf. & & & & \\
\hline
\end{tabular}




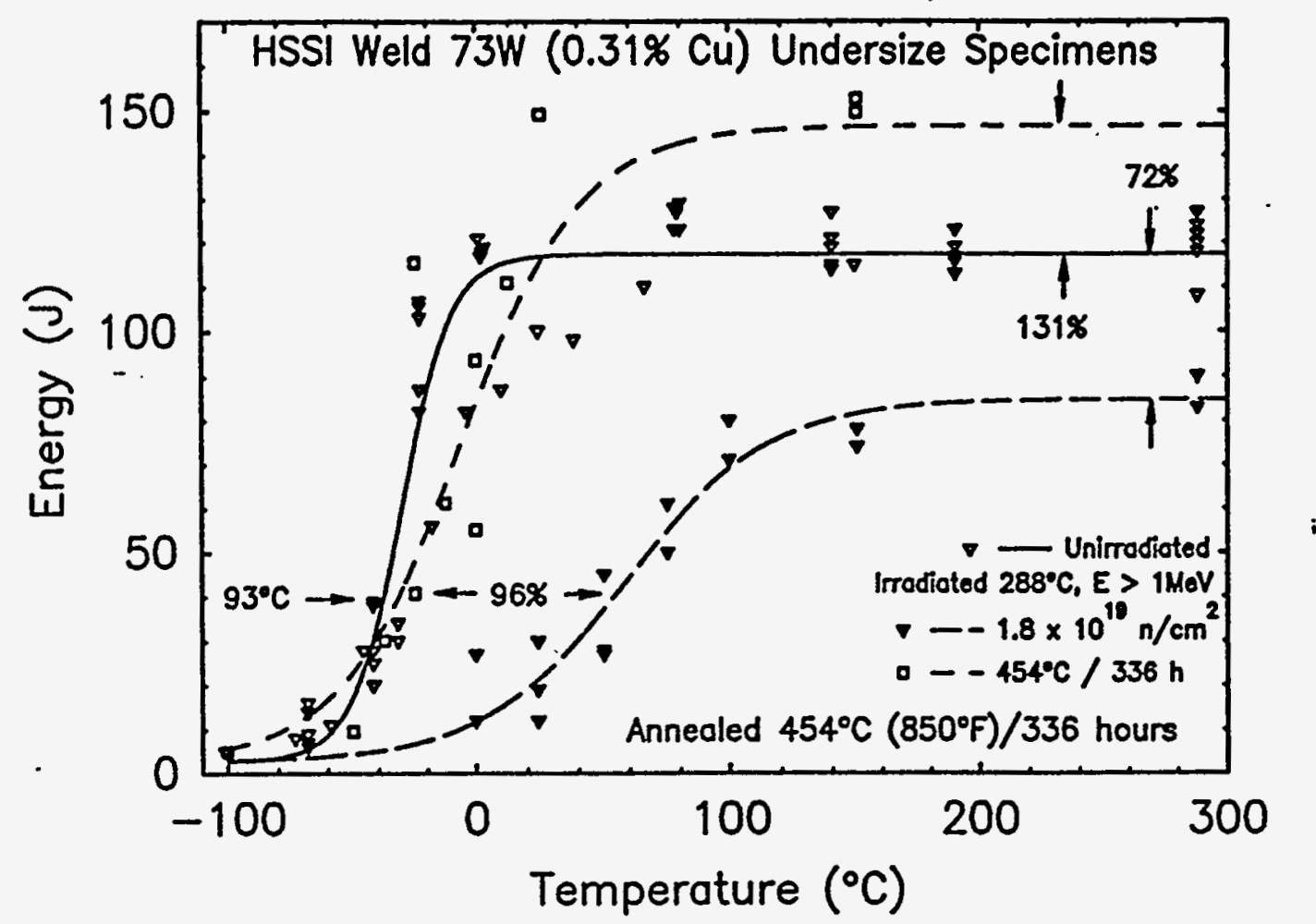

FIG. 8--Results of testing undersize irradiated Charpy V-notch specimens annealed at $454^{\circ} \mathrm{C}$ for $336 \mathrm{~h}$ compared to specimens in the unirradiated and irradiated conditions. The percent recovery is also indicated.

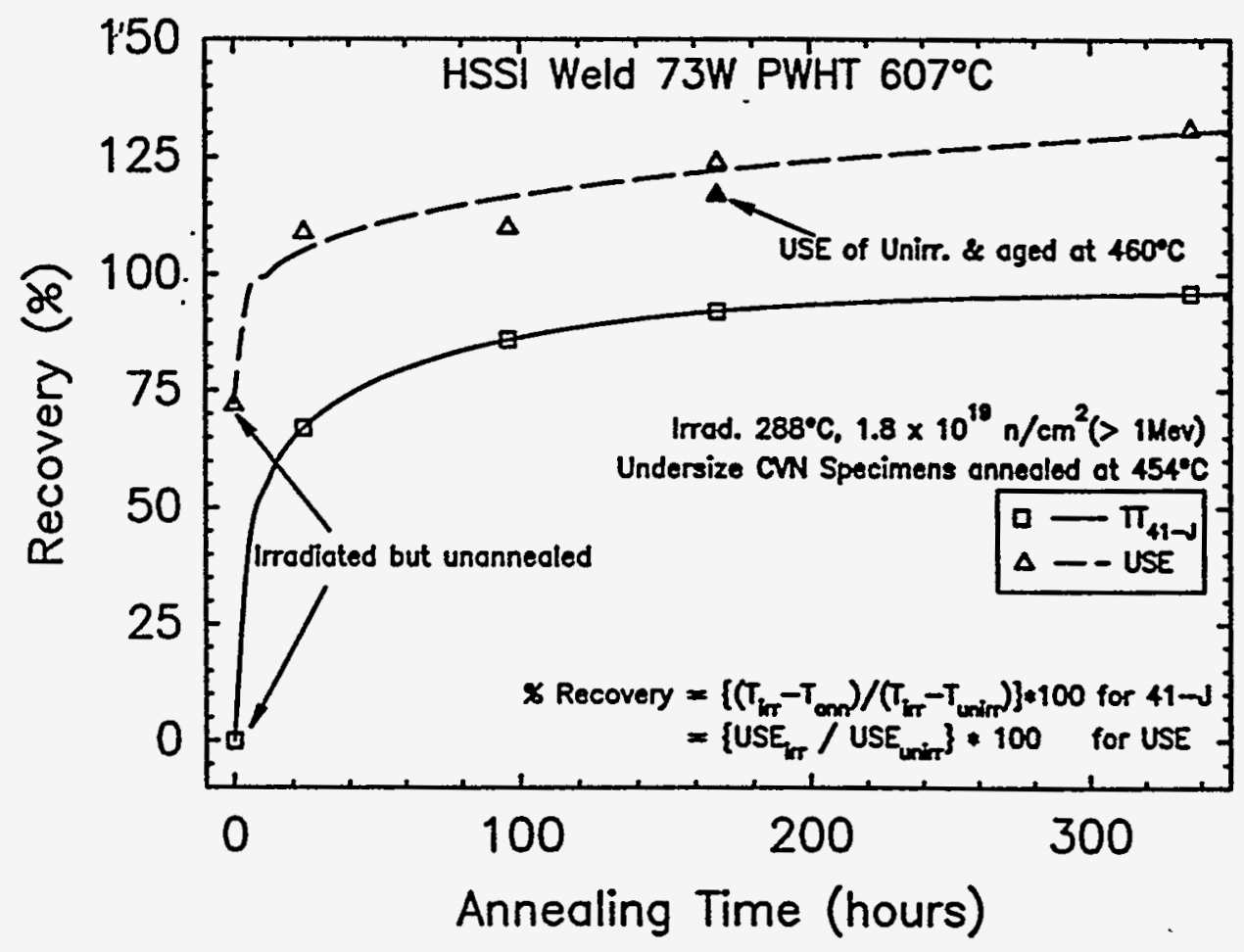

FIG. 9--Summary of percent recovery of the 41-J energy level transition temperature and the upper-shelf energy. 


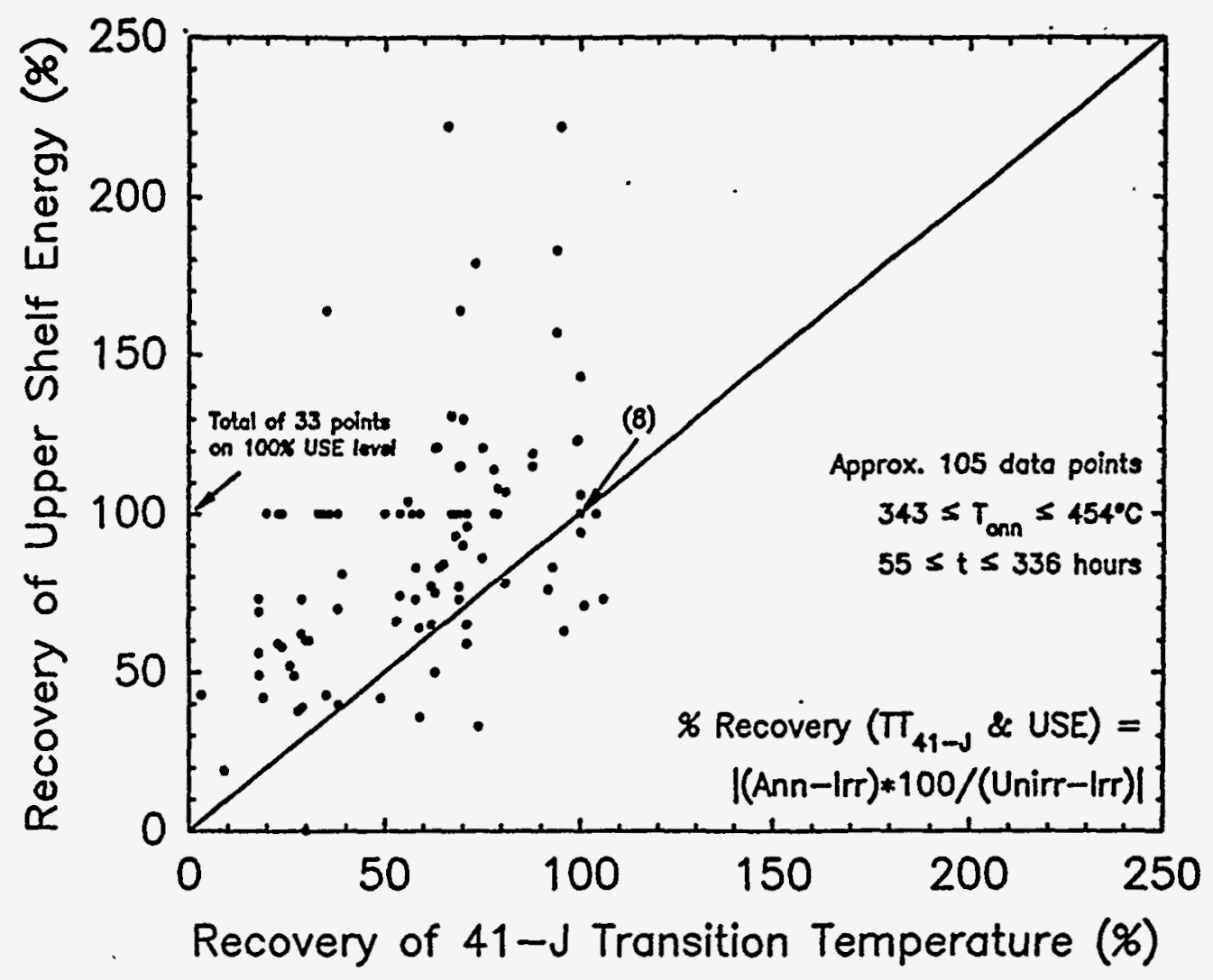

FIG. 10--Percent recovery of the upper-shelf energy versus percent recovery of the 41-J energy level transition temperature shift.

The rate of toughness degradation of irradiated and annealed RPV steels upon reirradiation is the present focus of investigations at ORNL. This is a major consideration in determining how long a RPV could be operated safely after it is annealed. It is possible that for some of the older RPVs for which annealing will be considered, no archival material is available, and the surveillance data from CVN specimens are the only data available that describe the rate of embrittlement. Thus, relating the rate of toughness degradation due to reirradiation to the rate of transition temperature shift of CVN specimens (the so-called "trend curve") from the unirradiated state becomes important.

\section{CONCLUSIONS}

HSSI weld 73W was annealed at two temperatures for various lengths of time. The following conclusions could be deduced from the results:

1. Annealing of HSSI weld $73 W$ has resulted in various degrees of recovery of the transition temperature and USE that depend strongly upon the annealing temperature and to a somewhat lesser degree upon the annealing time.

2. Annealing at $454^{\circ} \mathrm{C}$ for $24 \mathrm{~h}$ recovered about two-thirds of the transition temperature shift caused by the neutron irradiation. 
3. Annealing at $454^{\circ} \mathrm{C}$ for longer times increases the recovery, but at a decreasing rate, so that doubling the annealing time from 168 to $336 \mathrm{~h}$ increases the recovery from 92 to $96 \%$, which may not be a reasonable return for the extra annealing time invested.

4. Annealing at $343^{\circ} \mathrm{C}$ has resulted in an insignificant recovery of the transition temperature and a relatively small recovery in the USE.

5. Annealing at $454^{\circ} \mathrm{C}$ for various lengths of time from 24 to $336 \mathrm{~h}$ has "over-recovered" the USE to values that exceeded the unirradiated values.

6. Over-recovery of the USE was also observed after aging the unirradiated weld at 460 and $490^{\circ} \mathrm{C}$ for 1 week, and thus over-recovery is not solely associated with recovery of irradiation-induced damage.

The reasons for the over-recovery of the USE in the unirradiated and irradiated conditions are still not understood, particularly since HSSI weld $73 \mathrm{~W}$ has been postweld heat treated at $607^{\circ} \mathrm{C}$ for $40 \mathrm{~h}$. The HSSI Program will continue to investigate this phenomenon.

\section{ACKNOWLEDGMENTS}

This research was sponsored by the Office of Nuclear Regulatory Research, Division of Engineering Technology, U.S. Nuclear Regulatory Commission, under Interagency Agreement DOE 1886-8109-8L with the U.S. Department of Energy under contract DE-AC05-84OR21400 with Lockheed Martin Energy Systems. The authors gratefully acknowledge the financial support and encouragement provided by the U.S. Nuclear Regulatory Commission, particularly A. Taboada and M. G. Vassilaros, the previous and present HSSI Program Monitors, respectively. The authors also wish to thank R. E. Stoller, and the ASTM reviewers for their helpful comments, and J. L. Bishop for preparation of the camera-ready manuscript.

\section{REFERENCES}

[1] A. M. Kryukov, and M. A. Sokolov, "Investigation of Material Behavior Under Reirradiation after Annealing Using Subsize Specimens, " pp. 417-423 in Small Specimen Test Techniques Applied to Nuclear Reactor Vessel Thermal Annealing and Plant Life Extension, ASTM STP 1204, W. R. Corwin, F. M. Haggag, and W. L. Server, Editors, American Society for Testing and Materials, Philadelphia, 1993.

[2] ASME Boiler and Pressure Code, An American National Standard, 1992 Addenda, Section XI, Article A-4000, American Society of Mechanical Engineers, New York, December 31, 1992. 
[3] R. K. Nanstad, F. M. Haggag, D. E. McCabe, S. K. Iskander, K. O. Bowman, and B. H. Menke, Martin Marietta Energy Systems, Inc., Oak Ridge Natl. Lab., Irradiation Effects on Fracture Toughness of Two High-Copper Submerged-Arc Welds, HSSI Series 5, USNRC Report NUREG/CR-5913, Vol. 1 (ORNL/TM-12156/V1), August 1992.

[4] R. K. Nanstad, D. E. McCabe, Blaine H. Menke, S. K. Iskander, and F. M. Haggag, "Effects of Irradiation on $\mathrm{K}_{\mathrm{Ic}}$ Curves for High-Copper Welds," pp. 214-233 in Effects of Radiation on Materials, 14th International Symposium, (Volume II), ASTM STP 1046, N. H. Packan, R. E. Stoller, and A. S. Kumar, Editors, American Society for Testing and Materials, Philadelphia, 1990.

[5] S. K. Iskander, W. R. Corwin, and R. K. Nanstad, Martin Marietta Energy Systems, Inc., Oak Ridge Natl. Lab., Results of Crack-Arrest Tests on Two Irradiated High-Copper Welds, USNRC Report NUREG/CR-5584 (ORNL/TM-11575), December 1990.

[6] S. K. Iskander, W. R. Corwin, and R. K. Nanstad, "Effects of Irradiation on Crack-Arrest Toughness of Two High-Copper Welds, " pp. 251-269 in Effects of Radiation on Materials: 15th International Symposium, ASTM STP 1125, R. E. Stoller, A. S. Kumar, and D. S. Gelles, Editors, American Society for Testing and Materials, Philadelphia, 1992,

[7] S. K. Iskander, W. R. Corwin, and R. K. Nanstad, Martin Marietta Energy Systems, Inc., Oak Ridge Natl. Lab., Crack-Arrest Tests on Two Irradiated High-Copper Welds. Phase II: Results of Duplex-Type Specimens, USNRC Report NUREG/CR-6139, (ORNL/TM-12513), March 1994.

[8] R. K. Nanstad, D. E. McCabe, R. L. Swain, and M. K. Miller, Martin Marietta Energy Systems, Inc., Oak Ridge Natl. Lab., Chemical Composition and $R T_{N D r}$ Determinations for Midland Weld WF-70, USNRC Report NUREG/CR-5914 (ORNL-6740), December 1992.

[9] L. F. Miller, C. A. Baldwin, F. W. Stallmann, and F. B. K. Kam, Martin Marietta Energy Systems, Inc., Oak Ridge Natl. Lab., Neutron Exposure Parameters for the Metallurgical Test Specimens in the Fifth Heavy-Section Steel Irradiation Series Capsules, USNRC Report NUREG/CR-5019 (ORNL/TM-10582), March 1988.

[10] T. R. Major, and R. G. Lott, Thermal Annealing of an Embrittled Reactor Pressure Vessel, EPRI NP-6113-M, Electric Power Research Institute, Palo Alto, Calif., January 1989. 
[11] G. R. Odette, "Radiation-Induced Microstructural Evolution in Reactor Pressure Vessel Steels," pp. 137-148 in Microstructure of Irradiated Materials, Materials Research Society Proceedings, Vol. 373, I. M. Robertson et al., Editors, Materials Research Society, Pittsburgh, 1995.

[12] F. W. Stallmann, J. A. Wang, F. B. K. Kam, Martin Marietta Energy Systems, Inc., Oak Ridge Natl. Lab., TR-EDB: Test Reactor Embrittlement Data Base, Version 1, USNRC Report NUREG/CR-6076 (ORNL/TM-12415), January 1994. 